\title{
PENGARUH PEMBERIAN INSENTIF TERHADAP KINERJA KARYAWAN PADA INDUSTRI KERAJINAN KULIT “KARYA PAHALA GROUP” DI MAGETAN
}

\author{
Henrika Arliani \\ Mahasiswa Prodi Pendidikan Ekonomi FPIPS IKIP PGRI Madiun
}

\begin{abstract}
This result aims to determine employee incentive marketing in Leather Craft Industry "Karya Pahala Group" in Magetan, to determine employee performance marketing industry Leather Craft "Karya Pahala Group" in Magetan and to investigate the influence of incentives on employee performance marketing industry Leather Craft "Karya Pahala Group" in Magetan. Determination of the sample in this study using a sample that is saturated all the existing employees in the leather industry "Karya Pahala Group" in Magetan totaling 45 employees. Data collection using questionnaires and documentation. In the statistical methods used to analyze data product moment correlation with the independent variables and variable incentives tied to performance. To test the validity of the research hypothesis regression test was used to analyze the data using SPSS for Windows 16.0. The results showed that incentives have a positive effect as well as the performance of employees in the leather industry "Karya Pahala Group" in Magetan. It is derived from the value of the F test, the value of 39.583 while Fcount Ftable value of 4.067. On the other hand Sighit known value of 0.000 and a value of 0.05 Sigprob. This means that Fcount $\geq$ Ftable $(\geq 4.067$ 39.583) $\leq$ Sighit Sigprob (0.000 Sigprob $\leq 0.05)$. This means that in case of refusal $\mathrm{H}_{0}$ which indicates that there is influence between employee performance incentives on leather industry "Karya Pahala Group” in Magetan. Besides the regression coefficient obtained ( $\mathrm{t}$ test) with a value of 6.291 while the value tcount ttable of 1.681. On the other hand Sighit value of 0.000 and a value of 0.05 Sigprob. This means tcount $\geq$ ttable $(6.291 \geq 1.681)$ or $\leq$ Sighit Sigprob $(0.000 \leq 0.05)$. This means that in case of refusal $\mathrm{H}_{0}$ indicating that incentives have a different influence on employee performance. In addition the results obtained from testing the validity of the value of $\mathrm{r}_{\mathrm{xy}}$ $\geq 0.295$ rtabel. This means that all the questions in the questionnaire incentive is valid. Besides reliability test results obtained from the value of Cronbach's Alpha of 0.785 and $0.760>0.6$. This means that the data collected reliable (trustworthy).
\end{abstract}

Keywords: Incentives, Employee Performance.

\section{PENDAHULUAN}

Menurut G. R. Terry (dalam Suwatno, 2011:234) "Latteryincentive means that which incites or a tendency to incite action”. Insentif merupakan sesuatu yang merangsang minat untuk bekerja. Pemahaman ini merupakan pendapat yang baik apabila diterapkan pada suatu perusahaan, karena kinerja dan produktivitas perusahaan akan meningkat. "Insentif ialah sesuatu yang mendorong atau mempunyai kecenderungan untuk merangsang suatu kegiatan, Insentif adalah motif-motif dan imbalan-imbalan yang dibentuk untuk memperbaiki produksi” (Andrew F. Sikula dalam 
Justine T. Sirait, 2006:200). Dari beberapa pendapat tersebut dapat disimpulkan bahwa insentif merupakan salah satu motivasi yang diberikan kepada karyawan untuk meningkatkan prestasi kerja.

Arti kinerja sebenarnya bersal dari kata-kata job performance dan disebut juga actual performance atau prestasi kerja atau prestasi sesungguhnya yang telah dicapai oleh sesorang karyawan. Pengertian kinerja (performance) adalah gambaran mengenai tingkat pencapaian pelaksanaan suatu kegiatan/program/kebijakan dalam mewujudkan sasaran, tujuan, misi dan visi organisasi yang tertuang dalam strategic planning suatu organisasi (Mohamad Mahsun, 2006:25). Menurut Sedarmayati (2009:180), kinerja merupakan hasil dari fungsi pekerjaan atau kegiatan tertentu selama periode tertentu. Kinerja merupakan hasil yang dicapai seseorang menurut ukuran yang berlaku, dalam kurun waktu tertentu, berkenaan dengan pekerjaan serta perilaku dan tindakannya (Suwatno dan Donni, 2011:196).Dari beberapa pendapat tersebut dapat disimpulkan bahwa kinerja adalah hasil dari tingkat pencapaian pelaksanaan seseorang dalam kurun waktu tertentu dalam suatu organisasi.

Insentif menghubungkan penghargaan dan kinerja dengan memberikan imbalan kinerja tidak berdasarkan senioritas atau jam bekerja. Meskipun insentif diberikan kepada kelompok, mereka sering menghargai perilaku individu.Program insentif dirancang untuk meningkatkan motivasi kerja pekerja. Program insentif dapat berupa insentif perorangan, insentif untuk seluruh perusahan, dan program tunjangan (Wibowo,2011:355).

Keberhasilan suatu perusahaan dalam mencapai tujuan yang telah ditetapkan bergantung pada orang-orang yang berada dalam lingkungan perusahaan tersebut. Salah satu cara yang dapat ditempuh oleh perusahaan dalam mencapai tujuannya adalah dengan meningkatkan kualitas kerja para karyawannya. Pemberian insentif oleh perusahaan merupakan upaya untuk memenuhi kebutuhan karyawan. Karyawan suatu perusahaan akan bekerja lebih giat dan semangat sesuai dengan harapan perusahaan, jika perusahaan memperhatikan dan memenuhi kebutuhan para karyawannya, baik kebutuhan yang bersifat materi maupun kebutuhan yang bersifat non materi.

Industri kerajinan kulit "Karya Pahala Group” merupakan sebuah perusahaan yang bergerak dalam bidang industri yang menjual produk dari kulit.Industri kerajinan kulit "Karya Pahala Group” bukan satu-satunya perusahaan yang memasarkan produk-produk dari kulit, namun banyak perusahaan lain sebagai pesaing yang memproduksi dan menjual produk yang sama. Dengan banyaknya pesaing yang dihadapi industri kerajinan kulit "Karya Pahala Group” menyebabkan perusahaan ini mengalami banyak kendala dalam meningkatkan kinerja karyawan.

Guna menghadapi persaingan antar perusahaan yang bergerak di bidang penjualan yang sama dan untuk mencapai keunggulan yang kompetitif, maka perusahaan memilih untuk meningkatkan kinerja karyawan dalam memasarkan produk penjualan. Dalam meningkatkan kinerja karyawan, perusahaan memberikan program insentif yang bertujuan untuk memperkuat hubungan kinerja dan memotivasi karyawan yang bekerja di industri kerajinan kulit 'Karya Pahala Group” maka dari itu pemberian insentif diharuskan tepat waktu.

Dalam uraian tersebut jelaslah pemberian insentif yang tepat waktu bagi karyawan dapat meningkatkan kinerja karyawan industri kerajinan kulit “Karya Pahala Group” di Magetan pula. Pemberian insentif yang tidak tepat waktu dan jumlah insentif yang relatif akan membuat karyawan tidak semangat dalam bekerja yang pada akhirnya akan menurunkan kinerja mereka dalam melaksanakan tugas-tugas perusahaan sehingga dapat menurunkan laba perusahan.

\section{METODE PENELITIAN}

Tempat penelitian ini dilakukan di Industri Kulit “Karya Pahala Group” Jalan Diponegoro 18 dan Jalan Sawo 8, Magetan.Adapun yang menjadi subyek penelitian adalah karyawan dari industri kulit "Karya 
Pahala Group” di Magetan.Variabel yang digunakan dalam penelitian ini terdiri dari dua macam variabel. Variabel bebas dan variabel terikat.

Rancangan penelitian yang digunakan dalam penelitian ini adalah penelitian kausalkomparatif untuk menyelidiki kemungkinan hubungan sebab-akibat berdasarkan atas pengamatan terhadap akibat yang ada.

Dalam penelitian ini variabel bebas (X) adalah pemberian insentif diambil menggunakan kuesioner dengan skala likert. Indikator variabel ini 1.berdasarkan jabatan atau kedudukan ada 3 butir, 2. berdasarkan prestasi kerja ada 4 butir, dan 3. berdasarkan laba perusahaan ada 3 butir. Jadi untuk variabel pemberian insentif ada 10 butir.

Variabel terikat (Y) adalah kinerja karyawan diambil menggunakan kuesioner dengan skala likert.Indikator variabel ini 1. Berdasarkan proses kerja dan kondisi pekerjaan ada 3 butir, 2. berdasarkan waktu yang dipergunakan atau lamanya melaksanakan pekerjaan ada 3 butir, dan 3 . bedasarkan ketepatan dan kuantitas pekerjaan ada 4 butir. Jadi untuk variabel kinerja karyawan ada 10 butir.

Menurut Suharsimi Arikunto (2010: 174) "sampel adalah sebagian atau wakil populasi yang diteliti”. Penelitian ini merupakan penelitian populasi karena semua anggota populasi dijadikan subjek penelitian.Adapun yang menjadi sampel dalam penelitian ini yaitu seluruh karyawan Industri Karya Pahala bagian produksi yang berjumlah 45 orang.

Teknik analisis data menggunakan SPSS for Windows 16.0.Teknik analisis data yang digunakan dalam penelitian ini adalah uji validitas guna untuk mengukur sah atau valid tidaknya suatu kuesioner.Untuk mengukur variabel keputusan pembelian jawaban responden menggunakan analisis butir yaitu dengan cara skor-skor yang ada kemudian dikorelasikan dengan menggunakan rumus korelasi product moment.

Ujireliabilitas menggunakan rumus uji cronbach's alpha. Metode pengambilan keputusan pada uji reliabilitas biasanya menggu- nakan batasan 0,6. Reliabilitas 0,6 adalah kurang baik, sedangkan 0,7 dapat diterima dan di atas 0,8 adalah baik (Sekaran dalam Duwi Priyatno, 2010: 32). Untukmengukur suatu kuesioner yang merupakan indikator dari variabeluji hipotesis dengan metode regresi linier sederhana dengan menggunakan uji $\mathrm{F}$ dan uji t untuk mengetahui signifikansi dari hipotesa dalam penelitian.Suatu kuesioner dikatakan reliabel jika jawaban seseorang terhadap pertanyaan adalah konsisten atau stabil dari waktu kewaktu.

\section{HASIL PENELITIAN}

Setelah kuesioner terkumpul, peneliti menemukanbagaimana pengaruh pemberian insentif terhadap kinerja karyawan di industri kerajinan kulit "Karya Pahala Group” di Magetan sebagai berikut.

1. Uji Validitas

Hasil dari perhitungan untuk uji validitas angket pemberian insentif karyawan dan angket kinerja karyawan dapat diketahui dari nilai $r_{x y} \geq r_{\text {tabel }}$ sebesar 0,294. Dari hasil tersebut dapat disimpulkan bahwa semua soal yang ada dalam angket pemberian insentif dan angket kinerja karyawan adalah valid dan dapat digunakan dalam penelitian.

2. Hasil Uji Reliabilitas

Dalam uji reliabilitas ini dilakukan dengan rumus uji cronbach's alpha. Dari hasil uji reliabilitas terhadap angket pemberian insentif dan kinerja karyawan diperoleh nilai Cronbach's Alpha masing-masing sebesar 0,785 dan 0,760. Karena nilai Cronbach's Alpha lebih dari 0,6, dapat disimpulkan bahwa data yang dikumpulkan melalui angket pemberian insentif dan kinerja karyawan reliabel (dipercaya). Oleh karena itu angket pemberian insentif dan kinerja karyawan dapat digunakan sebagai alat pengumpul data dalam penelitian

3. Hasil Uji Regresi

Dalam uji regresi pada tabel anova dihasilkan F sebesar 39,583 berati bahwa $\mathrm{F}_{\text {hitung }}$ $\geq F_{\text {tabel }}(39,583 \geq 4,067)$ atau $\operatorname{Sig}_{\text {hit }} \leq \operatorname{Sig}_{\text {prob }}$ 
$(0,000 \leq 0,05)$. Dengan demikian $\mathrm{H}_{0}$ ditolak, artinya pemberian insentif memiliki pengaruh terhadap kinerja karyawan pada Industri Kerajinan Kulit "Karya Pahala Group” di Magetan. Sedangkan dari uji t pada tabel coefficientsdapat diketahui bahwa nilai $t_{\text {hitung }}$ sebesar 6,291 $\geq \mathrm{t}_{\text {tabel }}$ sebesar 1,681 atau nilai Sig $_{\text {hit }}$ sebesar 0,000 $\leq$ Sig $_{\text {prob }}$ sebesar 0,05. Dari hasil uji t tersebut dapat dikatakan bahwa $\mathrm{H}_{0}$ ditolak artinya terdapat beda pengaruh antara pemberian insentif terhadap kinerja karyawan pada Industri Kerajinan Kulit "Karya Pahala group” di Magetan. Hasil dari analisis data yang dilakukan dalam penelitian ini diambil simpulan untuk uji regresi persamaan regresi adalah sebagai berikut:

$\mathrm{Y}=13,426+0,653 \mathrm{X}$

Dari hasil uji regresi di atas dapat disimpulkan bahwa persamaan tersebut jika pemberian insentif meningkat sebesar $1 \%$, kinerja karyawan akan meningkat 0,653\%, dengan faktor lain dianggap tetap.

4. Variabel pemberian insentif (X)pada industri kerajinan kulit "Karya Pahala Group” di Magetan dalam upaya meningkatkan kinerja karyawandapat dideskripsikan bahwa variabel pemberian insentif dengan jumlah data (n) sebanyak 45 orang memiliki deskripsi data sebagai berikut: (a) Nilai total skor sebesar 1726; (b) Nilai mean sebesar 38,36; (c) Nilai median sebesar 38,00; (d) Nilai modus sebesar 37; (e) Standar deviasi sebesar 4,354; (f) Nilai minimum sebesar 29; (g) Nilai maksimum sebesar 46.

5. Variabelkinerja karyawan (Y) pada perusahaan Industri Kerajinan Kulit "Karya Pahala Group” di Magetan yang telah diteliti terdapat dari angket, dapat dideskripsikan bahwa variabel kinerja karyawan dengan jumlah data (n) sebanyak 45 orang memiliki deskripsi data sebagai berikut: (a) Nilai total skor sebesar 1732; (b) Nilai mean sebesar 38,49; (c) Nilai median sebesar 39,00; (d) Nilai modus sebesar 35; (e)
Standar deviasi sebesar 4,110; (f) Nilai minimum sebesar 30; (g) Nilai maksimum sebesar 45.

6. Pemberian insentif mempengaruhi kinerja karyawan. Hal ini dapat dari hasil uji regresi $\mathrm{Y}=13,426+0,653 \mathrm{X}$ yang artinya jika pemberian insentif meningkat sebesar 1\% maka kinerja karyawan akan meningkat 0,653X. Dalamuraian tersebut jelaslah pemberian insentif bagi karyawan dapat mempengaruhi kinerja karyawannya pula. Pemberian insentif yang tidak tepat waktu dan jumlah insentif yang relatif akan membuat karyawan tidak semangat dalam bekerja yang pada akhirnya akan menurunkan kinerja mereka dalam melaksanakan tugas-tugas perusahaan sehingga dapat menurunkan laba perusahan.Dalam meningkatkan kinerja karyawan, perusahaan memberikan program insentif yang bertujuan untuk memperkuat hubungan kinerja dan memotivasi karyawan yang bekerja di industri kerajinan kulit ‘Karya Pahala Group” maka dari itu pemberian insentif diharuskan tepat waktu.

\section{PEMBAHASAN}

Hasil dari uji penelitian ini menyatakan bahwa pemberian insentif mempunyai pengaruh terhadap kinerja karyawan.

\section{Uji Regresi}

Dapat dilihat dari hasil persamaan regresi yaitu $Y=13,426+0,653 X$. Yang artinya pemberian insentif yang baik untuk mematuhi peraturan dapat meningkatkan kinerja karyawan.Karena pemberian insentif merupakan jumlah yang dihasilkan dan jumlah setiap sumber yang dipergunakan selama kinerja berlangsung.

\section{Pembahasan Uji F}

Hasil uji Fisher dapat diketahui bahwa nilai Fhitung sebesar 39,583 sedangkan nilaiFtabel sebesar 4,067. Di lain pihak diketahui nilai Sighit sebesar 0,000 dan nilai Sigprob besarnya 0,05. Hal ini berarti bahwa 
Fhitung $\geq$ Ftabel $(39,583 \geq 4,067)$ atau Sighit $\leq$ Sigprob (0,000 d" 0,05). Dengan demikian H0 ditolak, artinya pemberian insentif memiliki pengaruh terhadap kinerja karyawan pada Industri Kerajinan Kulit “Karya Pahala Group” di Magetan.Dari hasil perhitungan yang diperoleh, bahwa memang terdapat pengaruh antar pemberian insentif dengan kinerja karyawan.

\section{Pembahasan Uji t}

Untuk uji t diperoleh nilai thitung $(6,291)$ e” ttabel $(1,681)$ atau Sighit $(0,000)$ d" Sigprob pada taraf signifikansi 0,05 . Dengan hal ini H0 ditolak, artinya ada beda pengaruh pemberian insentif terhadap kinerja karyawan pada Industri Kerajinan Kulit “Karya Pahala Group” di Magetan.

\section{KESIMPULAN DAN SARAN}

\section{Kesimpulan}

1. Pemberian insentif yang ada pada Industri kerajinan Kulit "Karya Pahala Group” di Magetan dengan hasil mean 38,36, median 38,00 , modus 37 , minimum 29 , dan maximum 46. Hal ini terbukti dari industri tersebut yang memberikan insentif sesuai kebutuhan dan prestasi kerja karyawan yang bersangkutan, dengan pemberian insentif yang baik pada akhirnya membuat kinerja karyawan meningkat

2. Kinerja karyawan yang ada pada Industri kerajinan Kulit “Karya Pahala Group” di Magetan dengan hasil mean 38,49, median 39,00, modus 35, minimum 30, maximum 45. Hal tersebut terbukti dari karyawan yang selalu melaksanakan pekerjaan penuh dengan tanggung jawab dan memaksimalkan hasil pekerjaan yang diberikan kepadanya

3. Terdapat pengaruh yang positif antara pemberian insentif terhadap kinerja karyawan. Hal ini terlihat dari uji regresi $\mathrm{Y}=$ 13,426+0,653X yang artinya jika pemberian insentif meningkat sebesar $1 \%$ maka kinerja karyawan akan meningkat 0,653\% . Hal tersebut didukung oleh hasil penelitian yang menunjukkan bahwa uji Fisher di- peroleh nilai $\mathrm{F}_{\text {hitung }}$ sebesar 39,583 $\geq \mathrm{F}_{\text {tabel }}$ sebesar 4,067 atau nilai Sig $_{\text {hit }}$ sebesar 0,000 $\leq$ Sig $_{\text {prob }}$ sebesar 0,05 dan uji t, nilai $t_{\text {hitung }}$ sebesar 6,291 $\geq t_{\text {tabel }}$ sebesar 1,681 atau nilai Sig $_{\text {hit }}$ sebesar 0,000 $\leq$ Sig $_{\text {prob }}$ sebesar 0,05. Hasil tersebut menyatakan bahwa $\mathrm{H}_{0}$ ditolak artinya terdapat pengaruh pemberian insentif terhadap kinerja karyawan pada Industri kerajinan Kulit "Karya Pahala Group” di Magetan.

\section{Saran}

1. Bagi Perusahaan

Pemberian insentif bagi karyawan besar pengaruhnya terhadap kinerja karyawan, oleh karena itu pemberian insentif dapat meningkatkan hasil kerja karyawan dalam perusahaan. Dengan pemberian insentif diharapkan karyawan dapat melaksanakan pekerjaan dan meningkatkan hasil kerjanya secara maksimal.

2. Bagi Karyawan

Bagi karyawan hendaknya menyadari dan termotivasi untuk berusaha melaksanakan pekerjaan dengan sungguh-sungguh agar pekerjaan selesai tepat waktu dengan hasil yang maksimal pula

\section{DAFTAR PUSTAKA}

Algifari. 2003. Statistika Induktif. Yogyakarta: Akademi Manajemen Perusahaan YKPN.

Anwar Mangkunegara. 2005. Evaluasi Kinerja SDM. Bandung: PT.Refika Utama.

Burhan Bungin. 2005. Metodologi Penelitian Kuantitatif (Komunikasi, Ekonomi, dan Kebijakan Publik Serta Ilmu-ilmu Sosial Lainnya. Jakarta: Prenada Media.

Duwi Priyatno. 2010. Teknik Mudah dan Cepat Melakukan Analisis Data Penelitian dengan SPSS dan Tanya Jawab Ujian Pendadaran. Yogyakarta: Gava Media

Gabriel Amin Silalahi. 2003. Metodologi Penelitian dan Studi Kasus.Sidoarjo: CV Citramedia

Hassan Suryono. 2005. Statistik: Pedoman, Teori dan Aplikasi. Surakarta: LPPS UNS dan UPT Penerbitan \& Percetakan UNS. 
Iskandar. 2010. Metodologi Penelitian Pendidikan dan Sosial (Kuantitatif dan Kualitatif). Jakarta: Gaung Persada Press ( GP Press)

Sirait, Justin T 2006. Memahami Aspek PengelolaanSumber Daya Manusia Dalam Organisasi. Jakarta: PT. Grasindo.

Mohamad Mahsun. 2006. Pengukuran Kinerja Sektor Publik. Yogyakarta: BPFE.

Nanang Martono. 2010. Metode Penelitian Kuantitatif: Analisis Isi dan Analisis Data Sekunder. Jakarta: PT. Raja Gravindo Persada.

Sedarmayanti. 2009. Tata Kerja dan Produktivitas Kerja. Bandung. CV. Mandar Maju.
Sjafari Mangkuprawira. 2009. Bisnis, Manejemen, dan Sumberdaya Manusia. Bogor: IPB Press.

Suharsimi Arikunto. 2010. Prosedur Penelitian Suatu Pendekatan Praktik. Jakarta: PT. Rineka Cipta.

Suwatno dan Doni. 2011. Manajemen SDM dalam Organisasi Publik dan Bisnis.Bandung: Alfabeta.

Usman Rianse dan Abdi. 2009. Metodologi Penelitian Sosial dan Ekonomi (Teori dan Aplikasi) Bandung: CV. Alfabeta.

Wibowo. 2011. Manajemen Kinerja. Jakarta: PT. Rajagrafindo Persada. 